\title{
Participative opposition applied
}

\author{
L'udmila Lacková1
}

\begin{abstract}
Opposition theory is one of the main outcomes of structural linguistics of the last century. While it is still valid and used in the field of phonology, it has not had the same fortune in other linguistic disciplines and has been replaced by other theoretical concepts. The present paper aims to revisit the opposition theory, particularly Louis Hjelmslev's theory of participative opposition. Participative opposition seems to have a high application potential not only in linguistics but also in other scientific fields. The first part of the paper outlines a brief history of the binary opposition theory within structural linguistics, while the second part introduces the somewhat forgotten concept of participative opposition, shows its explanatory power and, finally, its possible applicability in biology.
\end{abstract}

Keywords: Louis Hjelmslev; opposition theory; participative opposition; protein synthesis; structuralism

\section{Structuralism then and now: What it was and what it was not}

For several decades of the last century, the term 'structuralism' could be used as a synonym for linguistics and also as a synonym for semiotics (at least in Europe). In recent days, structuralism belongs to history; some believe that recent linguistic and semiotic theories are in direct contradiction with structuralist ideas and that the new theories outshine the old structuralist mindsets.

Some structuralist thinking nevertheless survived in the domain of the humanities or philosophy even in the late 20th century and continues to do so even to the present day. The relational way of thinking, for which structuralism became famous, has continued in the philosophy of relationalism or relationist ontology of the French philosopher Bruno Latour - to mention one of the most influential recent descendants of relational thinking. Latour first presented his understanding

1 Department of General Linguistics, Palacký University in Olomouc, Czech Republic; e-mail: ludmila.lackova@upol.cz. 
of relationist ontology in The Pasteurization of France (Latour 1988), where he explained the impact of Pasteur's achievements in medicine by a whole network of factors, such as the development of the public hygiene system, keen colonial interests, etc., rather than as mere acting of one scientist. Latour further developed the idea of relationism in We Have Never Been Modern (Latour 1993: 91-129).

Topology is another concept based on relational thinking, which was developed probably prior to linguistic structuralism, namely in mathematics in the pioneering work of Ludwig Euler, and has been recently rediscovered in the philosophy of science (Huneman 2010; 2018). Thanks to the work of René Thom, topology found applications even in semiotics. The concept of topology has been shown to suit biology and related branches of science - for instance, it is very effective in modern research of DNA spatial arrangement (Lindsely 2005).

When it comes to the notion of relationism within other branches of science, some scholars evoke quantum physics or the theory of relativity: the notion of relativity within physics is quite intuitive (Sedda 2017), and the application of Peirce's Logic of Relatives to the relation between particles in the context of quantum theory is, in this respect, interesting (Ketner, Beil 2006, 2012; Ketner et al. 2011). The link between Charles Sanders Peirce and structuralism will be explained below. The connection between structuralism, semiotics, and sciences is defined by Sedda (2017: 30$)$ as follows:

If the hard sciences can lead one to think that, "what we refer to when we talk about reality" is a "net of relations"; if they can point out, as a task, "mastering the correlations" between us and the world; if they even reach the point of saying that "We are structures" (Rovelli 2014: 220-223), then it is perhaps worthwhile running the risk and saying that, indeed, semiotics - precisely because it is relationalist, and because it is hyperstructuralist - has something important to offer to contemporary thought. (Sedda 2017: 30)

Of course, there is nothing wrong with saying that the relations of a system determine its nature and, as a matter of fact, this is a way of honouring the basic preliminaries of the structuralist movement. Yet the observation about the relations between the parts of a given system determining its very nature cannot necessarily be associated with the structuralist movement in linguistics and semiotics. Surely, it was not linguistics that inspired the big theories in physics and other sciences in the 20th century. One might even say that it happened the other way round and that, in fact, the relational understanding did not emerge among linguists, but from science - to be more precise, from chemistry. I will elaborate on this speculation in the following section. 
In this section I attempt to prove that the relational explanations did not come from linguistics. By doing this, I do not intend to devalue the importance of the structuralist movement in linguistics - quite the opposite. Structuralism is presumed to be an outdated linguistic theory which came to the end of its existence with the arrival of the generative branch of linguistics. If we agree to admit that the relational explanations did not derive from structuralism but existed long before that, it would imply that the structuralist movement was not just a temporary vogue in linguistics developed during the first half of the 20th century, but part of a major, more important way of scientific thinking that had started before the beginning of the structuralist movement in linguistics and is still developing in other branches of science, even after the "official death" of structural linguistics.

Even though it is believed that linguistics went through a paradigmatic change of switching from structuralism to generativism, the paradigmatic switching has nothing to do with a detachment from relational explanations. The generativist branch of linguistics mostly focuses on syntax and, by the very definition of syntax itself in the generativist sense, it cannot be of other order than relational. Of course, I am not denying the arrival of a big paradigmatic change in linguistics in the second half of the 20th century, yet this change does not attack the most important theoretical preliminaries of linguistic structuralism. By the most important preliminary of linguistic structuralism I mean the set of relational explanations by which the foundation of the structuralist theory is characterized, and which was used to spread the theory to other fields of humanities, such as sociology, anthropology, or narratology. With the arrival of Chomskian linguistics, something very innovative happened in linguistics, but it did not, in fact, contradict the basic preliminaries of the preceding paradigm. Indeed, Chomsky's first, revolutionary publication was entitled Syntactic Structures (Chomsky 1957). This paper does not deal with the problem of the history of linguistic ideas nor dwell on a detailed explanation of the difference between structuralism and generativism. I will just say that probably one of the major differences between the two movements lies in the characterization of the nature of the linguistic structure: while for the former it is social, for the latter it is biological. Still, the fact remains that both theories build on relational explanations, both deal with structures.

Of course, the characteristics of the structure both theories build on do not constitute the only difference between generativism (as developed from distributionalism) and structuralism, but this difference is the most striking one from the perspective of this paper. The difference between the two linguistic schools also lies in the theoretical standpoint concerning the nature of linguistic units. While for structuralism a linguistic unit represents a link between the planes of sound and meaning (signifiant and signifié, or in Hjelmslev's terminology, the planes of 
form and expression), for the American tradition originating in distributionalism, a unit is rather exclusively defined within one language plane. Let us, for instance, consider phonemes: in distributionalism a phoneme is defined by an oppositional system on the phonological plane, while in structuralism a phoneme is necessarily defined both by relations on the phonological plane as well as by the meaning it differentiates (see Hjelmslev's commutation test). The link between expression and content is very important when it comes to the opposition theory because it completes the system of oppositions on one linguistic plane with a system of oppositions on another linguistic plane; the link is defined by the relation of arbitrariness.

Arbitrariness is probably the best-known concept of Saussure's and also the most misused one. In the context of this paper, it is important to note that also for Saussure, as for the rest of structuralist theoreticians, a linguistic sign defined by arbitrariness was always an inseparable complex of signifiant and signifié and, more importantly, the arbitrary relation concerns both the expression and the content planes. That is, the arbitrary relation exists both vertically, between the two planes, and horizontally, between the units of one and the same plane. This statement is an extension of Saussure's statement that arbitrary and differential are two correlative qualities (Saussure 1916: 163) and this idea was further developed by André Martinet (1957) who differentiated between the horizontal and the vertical axis of arbitrariness (see also Lacková 2019).

I have been suggesting that the relational explanations did not end with the end of the structuralist movement in linguistics, yet they probably had not even started with the movement. From where, then, did they arrive in early-20th-century linguistics? Most probably from chemistry. In reality, chemistry was one of the fields of modern science that achieved great results using relational explanations (due to chemical bonds creating the structure of a chemical atom) and several parallels between linguistics and chemistry were made in the course of the 20th century. To be more exact, it was the structural syntax and valency theory by the French linguist Lucien Tesnière (1959). The very notion of valency was indeed inspired by chemical terminology, but surprisingly, probably the first person to see a connection between chemical radicals and the structure of a sentence was Peirce. Here, we arrive at the controversy concerning a supposed dissimilitude, or even incongruity, between the semiotic theories by Peirce and by European structuralists. Still, despite the apparent divergence between the Peircean and the structuralist branches of semiotics, Peirce is just another example of the general nature of relational thinking in the last century. Relational thinking was not a realm of the structuralist movement; rather, it was a generalized approach in many disciplines - just to think of Peirce's relational logic, that certainly has much 
in common with the structuralist movement. To that end, once again, it is not the relational way of explanation that created an apparent bifurcation between Peirce and European semiotics. There are not many papers written on this topic, but see for instance Paolucci 2006, 2010 and 2017.

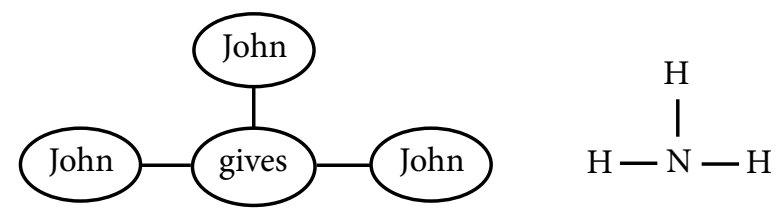

Figure 1. Relative terms.

Peirce commented on the figure (Fig. 1) as follows:

A chemical atom is quite like a relative in having a definite number of loose ends or "unsaturated bonds," corresponding to the blanks of the relative. In a chemical molecule, each loose end of one atom is joined to a loose end, which it is assumed must belong to some other atom [...]. Thus the chemical molecule is a medad, like a complete proposition. The proposition "John gives John to John" corresponds in its constitution, as Figs. 1 and 2 show, precisely to ammonia. (CP 3.469)

\section{Oppositions theory: A short excursion}

With the discovery of chemical bonds in chemistry, the relativity theory in physics, and the emergence of structuralist linguistics in the last century, we can see that it was relational thinking that brought together science and the humanities over the course of the last century, while it also continues to be an important science practice, e.g. in the study of DNA structure (Lindsely 2005). What makes structuralism to be perceived as an outdated theoretical matrix is not the relational thinking itself, but particular parts of the theory, mostly the binary opposition theory. The opposition theory is maybe the most famous structuralist heritage abandoned with the arrival of generativism in linguistics and the Peircean tradition in semiotics. Nonetheless, for some scholars the opposition theory is still valid, for instance in sociology or in cognitive science (Danesi 2009).

Similarly to the rest of structuralist theory, also the opposition theory finds its origins in the thought of Ferdinand de Saussure. Saussure (1916) based his conception of the linguistic system on pairs of oppositions such as langue-parole, synchrony-diachrony, signifiant-signifié, etc. To put it differently, the most 
striking traits of Saussure's linguistics were the notions of différence and valeur in the context of linguistic identity: a linguistic unit can only be defined by opposition to what it is not (negative identity), by which it differs from the other units of the system. What identifies signifiant is its difference from the signifie it denotes, on the one hand, and its difference from other signifiants on the other hand. The economic metaphor is often used to explain this double identity: one can exchange money for goods and, at the same time, the money enters into an opposition with the rest of the currency system. Saussurean binarism was further developed in many ways by several structuralist and semiotic schools, e.g. the Copenhagen School (Hjelmslev 1963), the Prague School (Trubetzkoy 1939), the Paris School (Greimas 1966, 1970), and also the Tartu School (Lotman 1991). In the context of the Tartu School, the specific term of ternary opposition (ternary structure) was introduced by Lotman (2009: 38-64, 166-171).

The most important significance of the opposition theory is associated with phonology. The phonological theory by Trubetzkoy based on oppositions and minimal pairs has until recently remained the only effective theoretical background for phonology.

Trubetzkoy (1939) elaborated a complex system of oppositions in phonology, using opposition pairs such as bilateral $v s$. multilateral or constant $v s$. neutralizable. Yet more famous than the oppositional pairs are the three types of oppositions proposed by Trubetzkoy: privative, gradual, and equipollent oppositions. The privative opposition lies at the centre of minimal phonological pairs. It is an opposition between two phonemes which share all features except a distinctive one, which is present in only one of them. Consequently, these phonemes are accordingly named 'marked' and 'unmarked'. As an example, we can take the feature of voice which is present in $/ \mathrm{b} /$ but absent in $/ \mathrm{p} /$, while the rest of the distinctive features the phonemes $/ \mathrm{p} /$ and $/ \mathrm{b} /$ have in common, both being bilabial plosives, are in a privative opposition. Gradual opposition is based not on the presence and absence of a feature, but on the degree of the presence of this feature, for instance the degree of openness in some vowels might put even more than two phonemes in an opposition. Equipollent opposition puts in contrast phonemes with more than just two positive differences; thus, this kind of opposition is not based on the presence/absence of a trait either.

Contrarily to phonology, application of the opposition system in morphology was not very successful and not many were interested in this topic besides Jakobson (1932).

Lastly, application of opposition theory to semantics should be mentioned - it was not met with a great success, yet it was an interesting attempt to see whether such a theory would work at the semantic level. As a result, componential analysis 
(Nida 1979) can be perceived as a compelling tool for semantic analysis. Also, until recent days the notion of semantic features partially survived in the form of experimental research in psycholinguistics and cognitive linguistics. For a detailed history of the theory of oppositions, see Danesi 2009.

When dealing with the opposition theory within the structuralist movement in linguistics, it is often overlooked that Hjelmslev elaborated an alternative idea of opposition. Besides his famous double pairs of form-substance and expressioncontent in Prolegomena to a Theory of Language (Hjelmslev 1963), Hjelmslev elaborated a rather less famous, but equally interesting theory of so-called participative opposition. Participative opposition is somehow in contradiction with the classic opposition theory stating a need of opposition to be exclusive, that is, the two terms entering into an opposition must exclude each other: either something is black or it is white, either a vowel is short or it is long, etc. Participative opposition, conversely, does not require the condition of exclusiveness, quite the contrary, the two terms entering into a participative opposition are participating in each other. In this manner, the opposition acquires another dimension, it is no longer exclusive, and, according to Hjelmslev, the linguistic system is based on this kind of relations. I will try to demonstrate that the participative opposition represents a very potent tool for not only linguistics but also other sciences, and we should reconsider it in light of the scientific knowledge of the last years. Thanks to the participative opposition, the structuralist movement could gain a little more consideration on the part of scholars of these days.

\section{Another side of structuralism: Participation as binarity without exclusion}

Louis Hjelmslev borrowed the term 'participation law' from the anthropology theory of Lévy-Bruhl (1927) and elaborated it in a way to create a theoretical instrument for linguistic analysis, taking for granted participation as a very constitutive character of language. He elaborated this theory primarily in two essays: La catégorie des cas (Hjelmslev 1935) and Structure générale des corrélations linguistiques (Hjelmslev 1985). The core idea of the participation law governing a linguistic system resided in that, as opposed to the mainstream of structuralist linguistics of those years, according to Hjelmslev, language is not analysable in terms of binary oppositions. Or better, it was not analysable in terms of exclusive binary oppositions. Hjelmslev himself, being one of the most influential structural linguists, did not deny binary relations in language, but concluded, in a sort of a compromise, that the binary oppositions governing language are not necessarily 
of an exclusive character - in other words, their terms do not exclude each other. To put it more simply, this means that the terms in the participative opposition may coexist without excluding each other.

According to the theory of Hjelmslev, participative oppositions are suitable for descriptions at the morphological and semantic language levels. In phonology, on the other hand, oppositions are rather exclusive ${ }^{2}$ - one phoneme cannot be anterior and posterior or labial and non-labial at the same time. The impossibility of superposing two contradictory features (distinctive features) at the same time guarantees the definition of a phonological unit: a phoneme is defined by exclusive oppositions, by phonemes with which it is in opposition: $/ \mathrm{p} /$ is $/ \mathrm{p} /$ because it is not $/ \mathrm{b} /$ with which it creates a binary opposition; $/ \mathrm{n} /$ is $/ \mathrm{n} /$ because it is not $/ \mathrm{n} /$ with which it creates a binary opposition. However, when we move from phonology to "upper" linguistic areas, such as morphology or lexicon, the definition of linguistic units by means of exclusive oppositions becomes more complicated. This is because the opposition theory works well when applied exclusively to one linguistic plane (i.e. phonological plane) but when we move to the morphological level, it becomes difficult, even impossible, to separate morphology from semantics. Morphological units are related to meanings they are associated with; therefore, we must necessarily consider semantics, and at that point the opposition theory touches more than one linguistic plane. For instance, the morpheme -s designating the third person in the English present simple tense is incomprehensible without the reference it denotes. We have the same problem with lexicon. It would be limiting to define, for instance, the word 'man' by an exclusive opposition with the word 'woman', since the meaning of the word 'man' is not limited to an opposition with the word 'woman'. For instance, in the sentence "All men are wise", the meaning of the word 'men' is not definable by its opposition to 'women'. Hjelmslev observed, however, that in some ways, there is a relation of opposition, and resolved it by calling this kind of opposition a participative opposition (borrowing the term from Lévy-Bruhl). The term 'women' is in opposition with the term 'men', but is also included within the very term 'men'. According to Hjelmslev, this paradoxical situation is by no means an exception within the language system, nor is it merely a particularity of semantics or lexicon. In a similar manner, all morphological categories are definable by participative oppositions. The case system, verbal tenses, gender, and number of substantives -

2 It should be remarked that, according to the phonological theory of the Prague School, the exclusiveness of the phonological oppositions is not that obvious. The Prague scholars suggested treating some of the phonological oppositions rather in a scalar manner than in terms of exclusive opposition. As a consequence, they differentiated between privative, gradual, and equipollent oppositions in phonology (Trubetzkoy 1939: 67-74). 
all these categories enter into participative oppositions. As a result, the accusative is opposed to the nominative, but is included within it by syncretism in some morphological paradigms. The plural is opposed to the singular, but is also included within it (imagine sentences such as "The dog was the first domesticated animal"). The past is opposed to the present, but is also included within it (in case of the historical present), etc.

How is the accusative included in the nominative, the plural in the singular, and the past in the present? Firstly, it is by syncretism of different functional units (nominative and accusative) in one morphological form (nominative) within a given paradigm. Secondly, it is by syncretism of different meanings (past, present) in one morphological form (present) in a specific context (the historical present, for instance). In the case of the plural and the singular, one can also speak of metonymy. The above-mentioned examples of participative opposition between cases, tenses, and the grammatical category of number illustrate the way language disobeys the laws of classical logic. By participative opposition, contradictory features coexist, with one and the same unit being accusative, vocative, and nominative, without losing its identity:

\begin{abstract}
A linguistic system is free in relation to the logical system that corresponds to it. It can be oriented differently on the axis of the logical system, and the oppositions it creates is subject to the law of participation: there is not an opposition between $\mathrm{A}$ and non- $\mathrm{A}$, the only oppositions in the linguistic system are between $\mathrm{A}$ on the one hand and $\mathrm{A}+$ non-A on the other hand. ${ }^{3}$ (Hjelmslev 1935: 214)
\end{abstract}

Hjelmslev points out the anti-logical nature of the linguistic system, a system in which the basic prerequisites of Aristotelian logic (identity law, law of the excluded third) do not work. Such a system is called a prelogical system. The prelogical system is at the base of language phenomena; however, it is possible to bring together the prelogical linguistic system and the system of classical formal logic. Hjelmselv calls this fusion a sublogical system, and claims that only a sublogical system can describe language phenomena correctly. In his words, in order to establish a sublogical system, we need to find a common basis for both prelogical and logical systems. This basis lies in a system of oppositions. Hjelmslev applied the sublogical system to the case theory in his essay La catégorie des cas (1935):

3 In the original: "Le système linguistique est libre par rapport au système logique qui lui correspond. Il peut être orienté différement sur l'axe du système logique; et les oppositions qu'il contracte sont soumises à la loi de participation: il ny a pas d'opposition entre A et non-A, il n'y a que des opposotions entre A d'un côté et $A+$ non-A de l'autre." Translations from French are by the author of the article, unless indicated otherwise. 
The structural principle governing the linguistic system of cases is by definition prelogical [...]. But it would be possible to bring the system of formal logic and that of language to a common principle which could be received in the sublogical system. The sublogical system is at the base of the logical system and the prelogical system at the same time. In order to give a general idea of the category in question, it is necessary to bring the logical and the prelogical back to a common base by projecting them on the sublogical level. (Hjelmslev 1935: 127) ${ }^{4}$
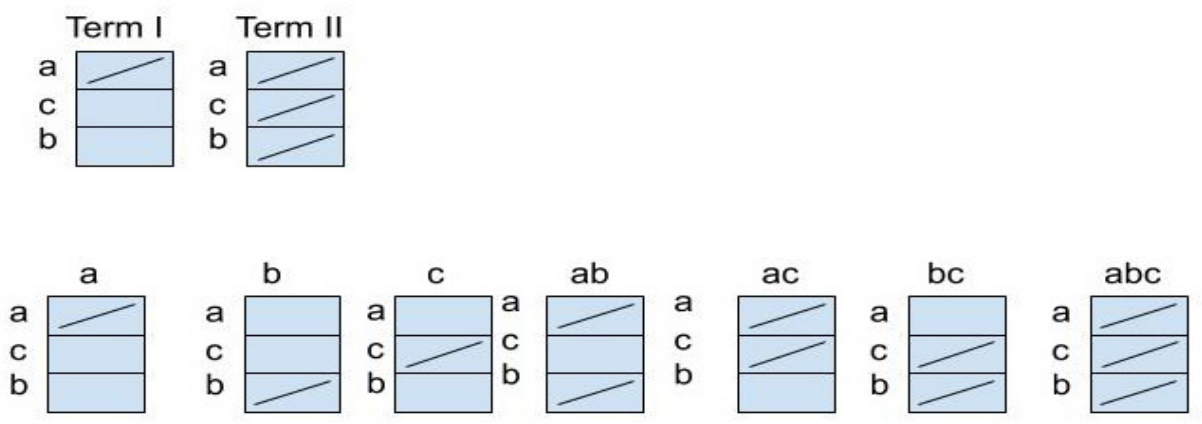

Figure 2. Schematization of a participative opposition. In the upper line we can see intensive term (Term I) and extensive term (Term II). In the lower line we can see the possible variations of the extensive term. Taken from Paolucci 2010: 55, inspired by Hjelmslev.

The core of the work of Hjelmslev lies in the opposition between an intensive (precise) term and an extensive (vague) term (Fig. 2). The fact that the exclusive oppositions are only applicable to one language level was used by Hjelmslev in his method of commutation test. This method works well because it is based on the either-or logical relation and it always concerns only one linguistic level:

The term 'commutation' has two main uses, which are moreover very related. For Hjelmslev, commutation is a 'function', that is to say, a relation, which exists between two members of a paradigm when the replacement of one by the other corresponds to a similar replacement on the other plane - the expression plane or the content plane as the case may be. Two members of a paradigm between which there is commutation are 'invariants'; otherwise, they are 'variants'. Regarding the

4 In the original: "Le principe structural dirigeant le système linguistique des cas est par définition prélogique [...]. Mais il serait possible de ramener le système de la logique formelle et celui de la langue à un principe commun qui pourrait recevoir celui de système sublogique. Le système sublogique est à la base du système logique et du système prélogique à la fois. Afin de donner une idée générale de la catégorie en question il faut ramener le logique et le prélogique à une base commune en les projetant sur le plan sublogique." 
nature of the paradigm, it is important here to remember only that the members of one paradigm are exclusive of each other or, as Hjelmslev says, that there is between them 'either-or function'. (Prieto 1960: 55) ${ }^{5}$

In Prieto's quote, a 'paradigm' means the plane of content or the plane of expression. Commutation is in fact a perfectly working method because switching between invariants is limited only to one semiotic plane. Yet at the same time it is also related to the other plane. Invariants are invariants as far as a change on one plane leads to an analogous change on the other plane. Prieto (1960:62) concludes:

This supposes that we have brought to light the particular point of view which guides this process of abstraction, which Saussure did in the CLG: linguistic entities result from the association of meaning and sound. Commutation is really just putting these principles into practice. ${ }^{6}$

Thus, commutation is proof of the fact that exclusive oppositions based on eitheror logical relations only exist within the boundaries of one semiotic level, but at the same time it is proof of the fact the two planes - the one of expression and the one of content - are necessarily inseparable and definable only in reference to each other. Hjelmslev's method of commutation is a tool using exclusive opposition, but, as Prieto points out, exclusive oppositions are limited to function only within one linguistic level. Therefore, commutation is mostly used in phonology, as phonemes differentiate meanings and create possible invariants and are very well describable by exclusive oppositions. Still, the method of commutation, when applied to higher linguistic planes, might lead to unsatisfactory results (see Faltýnek 2013). This might be caused by the fact that in morphology or semantics units are only barely definable by the exclusive opposition system. Hjelmslev was convinced that the logical relation of either-or type is not the only one existing in language, and he complemented this type of logical relations with already

5 In the original: "Le terme «commutation» a deux emplois principaux, d'ailleurs très apparentés. Pour Hjelmslev, la commutation est une «fonction», c'est-à-dire, un rapport, qui existe entre deux membres d'un paradigme lorsque le remplacement de l'un par l'autre correspond dans l'autre plan - le plan de l'expression ou le plan du contenu suivant le cas - à un remplacement analogue. Deux membres d'un paradigme entre lesquels il y a commutation sont des «invariantes»; sinon, ils sont des «variantes». En ce qui concerne la nature du paradigme, il est important ici de retenir seulement que les membres d'un paradigme sont exclusifs les uns des autres ou, comme dit Hjelmslev, qu'il y a entre eux «fonction ou» (either-or function)."

6 In the original "Cela suppose que l'on a mis en lumière le point de vue particulier qui guide ce processus d'abstraction, ce qu'a fait Saussure dans le CLG: les entités linguistiques résultent de lassociation du sens et de la phonie. La commutation nest en fait que la mise en pratique de ces principes." 
mentioned prelogical kind of participative relations. Hjelmslev is convinced of being a pioneer in the theory of participative opposition in linguistics. In fact, he claims: "Our work is without precedence. Not only has our problem so far found no solution. It has not even been proposed." (Hjelmslev 1985[1933]: 30) ${ }^{7}$

Nevertheless, in Structure générale des catégories linguistiques, he minutely analysed earlier works by the Russian linguists Peshkovskij, Karcevskij, and Jakobson, claiming that all three contributed to solving the issue of participative opposition. He was, however, trying to prove their incompleteness: none of them went further so as to reach the crux of the problem.

Hjelmslev surely elaborated the notion of participative opposition to an extent that no one had before him (after all, the very term is his invention), yet attributing originality to his work might seem inaccurate since he himself, perhaps due to distraction, equates his own terms with the terms by Peshkovskij. He demonstrates with an example of the nominative that Peshkovskij's concept of 'catégorie zéro' expresses the same meaning as his own 'term extensif': "The nominative is to the cases what the present is to the tenses. The nominative is what Mr Peshkovskij called catégorie zéro" (Hjelmslev 1935: 100) ${ }^{8}$.

The difference between catégorie zéro and an extensive term is, however, small, according to Hjelmslev, and lies in the fact that Peshkovskij states that catégorie zéro has no signification; in other words, it is characterized by the lack of meaning. An extensive term, on the contrary, guarantees a certain meaning. Does Peshkovskij actually claim, however, that zero category has no meaning? Is it not merely a rhetorical figure to argue that the meaning is extremely vague? Peshkovskij states that "lack of meaning constitutes a meaning in and of itself" (cited in Jakobson 1932: 3).

\section{Jakobson and markedness}

In continuation with Peshkovskij, Jakobson elaborated the idea of lack of meaning being meaningful in his essay "Signe zéro" (Jakobson 1971b). He replaced the notion of catégorie zéro with the more general concept of the signe zéro (zero sign). According to Jakobson, one can talk about two basic types of signe zéro - one which concerns the signifier, and another which concerns the signified. He argues that the so-called signe zéro represents one of the elementary morphological traits of a linguistic system: nominal and verbal systems are decomposed into

7 Originally appeared in 1933 in Travaux du cercle linguistic de Copenhague.

8 In the original: "Le nominative est aux cas ce qu'est l'indicatif aux modes, le présent aux temps. Le nominative est ce que M. Peškovskij a appelé une catégorie zéro". 
binary relations between a term indicating a mark (a marked term) and a term that expresses neither the presence nor the absence of the mark (signe zéro or unmarked term). This case is different from the classic concept of the notion zéro in phonology, where the zéro signifies the absence of a feature, for instance sonancy: a voiceless phoneme is in a relation of binary exclusive opposition with a voiced phoneme. Notion zéro in phonology relates to the signifier, to the phonological representation of a given signified. The kind of zéro that concerns the signified (Jakobson 1971b:212) is a case, however, in which the opposition is not between the absence or presence of a certain feature (mark), but between the presence of a mark and non-information about its absence or its presence. This is a case of opposition between, for example, the perfective and imperfective verbal aspect or between the grammatical genders.

It is difficult to understand Jakobson intuitively, since he treats both kinds of signe zéro in the same manner. The fact is that the difference between the two is of great importance within grammar theory and it is unfortunate that Jakobson did not expand on the difference between the two types of signe zéro. Very briefly, the basic difference resides in that one concerns the very linguistic form (phonological), while the other concerns the meaning. The choice of terminology is confusing as well: it is disconcerting to apply the term 'zero' to the level of content, since it somehow contradicts the very nature of the zero sign concept. The zero sign concept states that even there being no signifier actually means something. Even a zero may have a meaning (thanks to a paradigmatic opposition with other signifiers). Thus, if Jakobson argues that zero is the meaning of a grammatical category (imperfective, masculine gender, etc.), it is in order to argue to the contrary of the original zero sign concept which says that there are signifiers that have no meaning. What, however, would such a signifier be good for? What would it be good for when expressing 'nothing'? The problem is in the choice of terminology, which is certainly influenced by Peshkovskij's term 'catégorie zéro'. By using that term, however, Peshkovskij (1928) did not consider 'catégorie zéro' to have no meaning, but rather the opposite: he argued that "lack of meaning constitutes a meaning in and of itself".

Let us now return to Hjelmslev. Apart from the ambiguity of the meaning of 'catégorie zéro', the difference between Hjelmslev and the Russian linguists is quite blurred, although Hjelmslev was convinced there was an important novelty in his theory. Both the Russian theories and Hjelmslev's participative opposition seem quite alike: the law of participation (loi de participation) finds an equivalent in Russian theories as the law of substitution (loi de suppléance). Jakobson (1932: 2) uses the term 'concept of transposition'. The law of substitution, or concept of transposition, is explained by Jakobson (1932: 2) with the aid of the following example: 
The Russian word osël "donkey" contains no indication of the sex of the animal in question. If I say osël I make no decision as to whether I have to do with a male or with a female, but if I am asked èto oslíca? “Is it a she-ass?” And I answer nét, osël "no, donkey", then in this case the masculine gender is indicated.

The law of substitution resides in the fact that a grammatical category might be substituted by another grammatical category. In such a manner, the masculine gender substitutes the feminine gender: the Russian feminine substantive 'oslica' may be substituted by the masculine substantive 'osël'. Likewise, the English word 'man' can substitute the word 'woman', for instance in the sentence "All men are wise". As for grammatical categories, the situation is analogous. When it comes to verb tenses, the present (the so-called historical present) substitutes the past, in the case of historical present. When it comes to the category of number, the singular often works as a substitution for the plural. Concerning the category of case, the nominative, for instance, functions as a substitution for the accusative, etc. Many other examples may be found among linguistic categories. However, in order for a grammatical category to be substituted by another one, there must be a relation of participation between the two. 'Osël' and 'oslica' are in a relation of participation. The law of substitution in fact requires the law of participation, or, in other words, the participation law is a prerequisite for the substitution law. A linguistic category may replace another linguistic category only if the latter category participates in the former one. A linguistic category (a vague term) may substitute, in specific contexts, another category (a precise term), because the vague term, among all the meanings it encompasses, may also express the meaning of the precise term. Thus, Hjelmslev's notion of the law of participation is more about the very nature of language as a system, while the Russians' notion of the law of substitution is more about the practical consequences of the language use: as a principle of economy, the law of substitution permits the substitution of the accusative by the nominative, the substitution of the past by the present, or the substitution of the feminine by the masculine.

The difference between the markedness theory and Hjelmslev's participative opposition becomes clearer when we look at the meaning of the pairs of terms 'intensive'/'extensive' on the one hand and 'marked'/'unmarked' on the other hand. While the former pair of terms is of a functional character (defines functional relations within a given morphological category), the latter pair of terms expresses the semantics of a morphological category. In a paper dedicated to the critique of the markedness theory in morphology, the Czech linguist Miloš Dokulil (1957) concluded that the difference between functional and semantic understanding is the main gap between the Copenhagen and Jakobon's approaches. 

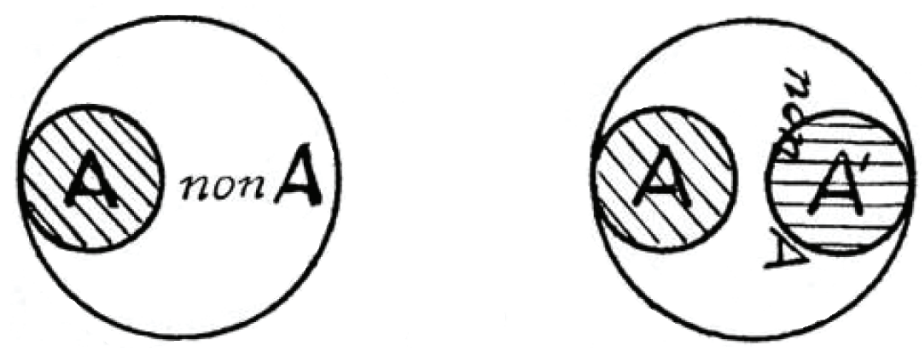

Figure 3. Jakobson's opposition between marked and unmarked term. A is a marked term, $A^{\prime}$ is a term contrary to A. Non-A is the unmarked term that occupies the entire semantic area of both A and A'. (Source: Miloš Dokulil 1957: 90.)

Let me comment on the last difference between Hjelmslev and Jakobson in their opposition theories. The opposition theory, from its binary nature, operates with two terms both in case of Hjelmslev and of Jakobson: marked/unmarked, intensive/extensive. Yet things are actually not that simple - in his formula of the participative opposition, Hjelmslev mentions not two, but three terms: A vs $\mathrm{A}+$ non-A, while Jakobson and others only use two terms: A vs non-A. Jakobson's morphological work was inspired by Trubetzkoy's system of phonological oppositions (Trubetzkoy 1939), but there is a significant difference between Jakobson's and Trubetzkoy's systems, and Jakobson demonstrates it in his essay "On the structure of the Russian verb" (Jakobson 1932). Jakobson applies the phonological structure to the morphological one and, starting from the very first page of his essay, he draws attention to the fact that the opposition in morphology has a specific nature, which allows the existence of a term with an internal contradiction. This means that this term, the unmarked term, may have different and even contradictory meanings (remember the case of 'osël'). The contradictory nature of the unmarked term is resolved thanks to the context: even if the meaning in itself is ambiguous or contradictory, there is no ambiguity once the context is given. 'Osël' is grammatically a masculine form, but it can also have a general meaning. Thus, depending on the context, the word 'osël' may mean 'donkey-masculine' or 'donkey-feminine' or 'both genders of donkey' or 'it is of no importance whether feminine or masculine'.

The feminine substantive 'oslica', on the other hand, only has one single meaning, which remains unvaried in every context, with this meaning being 'donkey-feminine'. 'Oslica' is a marked term. Therefore, when we place the Russian words 'osël' and 'oslica' in the formula of a participative opposition, we do not end up with a contradictory relation, but a relation of participation. As a consequence of this relation, the word 'osël' may substitute the feminine form 'oslica' (law of 
substitution). The unmarked term, in other words, extends its semantics to the whole area of marked term and its semantic antonyms, thus somehow meeting Hjelmslev's extensive term - for illustration, see Fig. 3.

As is shown in the figure, the space that non-A occupies is the entire space that also encompasses $\mathrm{A}$ and $\mathrm{A}$. Thus, a participative relation is illustrated between $\mathrm{A}$ and non-A. As a consequence, the seeming difference in the formulas $\mathrm{A} v s$ non-A and $\mathrm{A} v s \mathrm{~A}+$ non-A is not actually that straightforward. In the end, Jakobson's formula, at least as it is presented by Dokulil, also operates with three terms: A, A', non-A.

The difference between phonology and morphology, both using the same formula A vs non-A (marked vs unmarked), is striking. There is no space for the law of substitution in phonology. The lack of a mark is meant as a missing element, which by its non-presence distinguishes between two phonemes. To the contrary, in morphology, no lack of a mark is mentioned, there is only an indecision about its presence. To put it differently, there is no information about the fact whether the mark is or is not expressed. The unmarked term is undecided. Jakobson (1984[1958]:13) states clearly that "there is an antinomy between the non-signalization of A and the signalization of non-A".

Jakobson additionally distinguishes between two types of unmarked terms in morphology: one is the case of participative opposition, the other is the case of exclusive opposition. The Russian word 'osël' might happen to belong to both types of unmarked terms: the latter (exclusive opposition to the marked term) concerns a particular case which has to be determined by context. The specificity of Jakobson's approach resides in the fact that he considers the context to make up part of his grammatical theory. This is a special characteristic of the Prague School, to which Jakobson belonged. Unlike other schools of structuralism, the Prague School paid a great deal of attention to the role of communication, actual language use (parole), and not only language viewed in a systematic way (langue). ${ }^{9}$

To conclude this short theoretical introduction to the binaristic tradition in various structuralist approaches, the application of the opposition theory requires a modification of the classic opposition theory from phonology: exclusive opposition cannot hold for the complicated morphological system of a language. Both Jakobson's and Hjelmslev's applications of the opposition theory to morphology resulted in a modification where the specific relation between the two terms entering into an opposition was resolved either by the formula of $\mathrm{A}$ $v s \mathrm{~A}+$ non-A (Hjelmslev) or by the difference between non-signalization of $\mathrm{A}$

9 At this point I can cite the work by Vladimír Skalička entitled The Need for a Linguistics of 'la parole' (Skalička 1948). 
and the signalization of non-A (Jakobson). For more about the relation between Hjelmslev, Jakobson, and Russian linguists see also Andersen 1989.

Hjelmslev's formula of A vs A + non-A presupposes a coexistence of contradictory features - A and non-A as contradictory terms excluding each other, for instance 'man' and 'woman'. The logical problem of coexistence of contradictory features is resolved thanks to the differentiation between paradigm and syntagm. As a matter of fact, the supposed coexistence of contradictory elements exists at the paradigmatic level but disappears at the syntagmatical level, as was demonstrated above. In other words, the ambiguity of langue is resolved by the context in the act of parole.

\section{Some logical outcomes of the relation of participation}

At this point of our argumentation, it is important to look at some logical outcomes of the theory of participative oppositions. The definition of this type of relation as potentially violating the principle of the excluded middle might be problematic and requires major attention. At first sight it appears that the relation of participation is in fact a synonym for the classic logical relation of inclusion. The logical relation of inclusion is one of the three basic logical relations existing in language proposed by Jean Cantineau. And, surprisingly, according to Cantineau (1955: 5), Trubetzkoy's privative opposition is in fact an ideal example of the relation of inclusion. By analogy, privative phonological opposition should be considered as participative opposition, which is not exactly what Hjelmslev referred to in his works. Indeed, according to Cantineau, /p/ would be in a relation of inclusion with $/ \mathrm{b} /$ when the same mechanism of thinking as in markedness theory is applied: if ambiguity is maintained in morphology at the paradigmatic level, the situation is approximately the same in phonology. The two phonemes in privative opposition are in fact in opposition only thanks to the absence/presence of a trait and they are therefore in logical relation of inclusion; in other words, the 'marked' phoneme, i.e. the one in which a trait is present is included in the unmarked phoneme, a phoneme without this trait. From an articulatory-acoustic viewpoint, this is probably experimentally demonstrable. Thus, to state that $/ \mathrm{p} /$ and $/ \mathrm{b} /$ cannot coexist or that they exclude each other is analogous to stating that 'man' and 'woman' exclude each other, a statement disclaimed by the theory of participative opposition.

What we are facing here is a logical problem, but it is only an apparent problem which can be resolved thanks to discriminating between the syntagm and the paradigm. At the syntagmatic level, the coexistence of contradictory features 
disappears: I cannot pronounce two different phonemes at the same time, in this case /p/ and /b/. Thus, even if Hjelmslev in his theory of participative oppositions does not mention phonology, thanks to Cantineau's point we can conclude that participative opposition is a constitutive feature of language at all its levels.
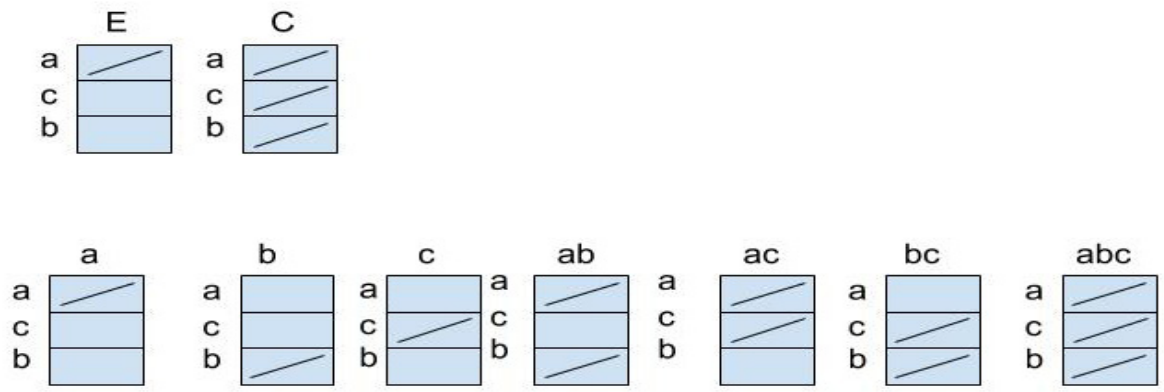

Figure 4. Relation of participation between expression and content - the upper line shows expression as an intensive term and content as an extensive term, while the lower line shows the possible variations of the content plane (from Paolucci 2010: 351, inspired by Hjelmslev 1985).

Additionally, participative opposition might represent the relation which brings together different planes of language, such as the expression and the content plane. This is what Paolucci (2010) actually proposed: comprehending the relation of participation between expression and content as the very constitutive feature of a sign. In fact, expression and content are not in a relation of exclusive opposition, rather, expression participates in the content in the way that expression constitutes a part of the content. They are not separable levels, yet somehow are understood as being in opposition, but this opposition can be called a participative opposition (Fig. 4).

If the relation of participative opposition is applied to the expression-content relation, it does not imply putting separate units of two different planes - two different planes of one semiotic system in a relation of opposition. Of course, it would be incorrect to say that phoneme /s/ enters into opposition with the singular, the former belonging to the phonological plane and the latter belonging to the morphological plane. What Paolucci probably had in mind when stating that expression and content, as two different semiotic levels, enter into a relation of participative opposition was explaining the complex relation between expression and content as notions, in the explanatory way of using the tool of participative opposition to explain the relation between these two semiotic notions. This is a very notable step in theoretical semiotics when questioning the relation between 
the content and the expression, yet it does not mean that we should put units of different semiotic planes into opposition. In other words: we can apply the relation of participative opposition to different semiotic planes when defining the very relation between them, but we cannot apply the same relation of participative opposition in a cross-plane way to units of different semiotic planes.

The most relevant outcome of Hjelmslev's notion of participative opposition is the following: the logical relation of inclusion existing at the paradigmatic level is opposed to the relation of exclusion at the syntagmatic level. What enters into opposition in the case of participative opposition is actually paradigmatic and syntagmatic realizations of the unit. A man (paradigmatic) enters into a relation with a woman (paradigmatic) and at the same time with a man (syntagmatic) and a woman (syntagmatic). The term 'participative opposition' can be analysed as consisting of 'participative' referring to the paradigmatic level and 'opposition' at the syntagmatic level. Since, as we have seen previously, the opposition in the sense of the contradictory relation of exclusion only comes into play at the syntagmatic level - until the moment of entering into a syntagm, the contradictory relation does not exist. When we comprehend the paradigmatic level exclusively, there is no possibility of violation of an excluded middle, since this presupposes a realization in time, and paradigm exists only in an abstract way, without any concrete time realization. Therefore, the syntagmatic part of the definition of participative opposition is necessarily needed in order to understand why we use (or Hjelmslev used) the notion of opposition at all. In other words, participative opposition is a notion with more potential than it was attributed. It embraces a possible trans-paradigmatic-syntagmatic tool for language description. Thus, even if it might seem paradoxical and anti-intuitive, the participative opposition in fact links two different language levels, paradigm and syntagm.

\section{Participative opposition in biology}

Participative opposition and the relation of participation is a concept that merits major attention. After Hjelmslev, the theory of participative oppositions was not developed further, except by the Tartu-Moscow School. The participative opposition theory was addressed mostly by Yurij Lekomtsev within his critical approach to the glossematic theory (Lekomtsev 1974). Lekomtsev considered the theory of opposition in the glossematic theory incomplete, mostly due to the lack of the combination law. Lekomtsev proposed a re-elaboration of the theory by fusing it with the differentiation theory. Consequently, he applied his theory to painting, semantics, and music. Lekomtsev also proposed a formalization of 
the opposition theory. With the exception of Lekomtsev, the theory was virtually abandoned together with the rest of the glossematic theory of the Copenhagen Structuralist School. However, it could find a new place within the current field of science. Despite constituting a part of the background of structuralist oppositions, participative opposition theory is based on oppositions which are not exclusive, and this fact directs it towards a very different application target. While exclusive oppositions have found their place in phonology and work perfectly in this capacity, participative oppositions may find application in other branches of linguistics - and not only there. The last section of this article illustrates a possible application of participative opposition theory in the field of biology.

Modern synthesis of the Darwinian theory contains numerous binary explanations. It is no coincidence that it was during the structuralist era in linguistics when the first analogies between the genetic script and natural languages arose. Jakobson himself was the first to comment on the common features between language and DNA (Jakobson 1971). Take, for instance, the binary relation between the genotype and the phenotype. The genotype is the complete set of genetic information of an organism, while the phenotype is the actual "embodiment" of the genetic information in a living body. The phenotype represents the actual traits and forms of the given organism. The classic dyadic explanations of modern synthesis comprehend the phenotype as imprints or blueprints of genotypes, that is, they presuppose a dyadic unequivocal correspondence between the genotype and the phenotype. Yet, in fact, organisms sharing one and the same genotype might differ significantly in their phenotypes. The modern synthetic approach does not offer further clarifications on how phenotypical variations are possible without a change in the DNA scripts (and also the other way round).

Recent studies in evolutionary biology, genomics, proteomics, epigenetics, and other life sciences point out the gaps in this binaristic model, based on an exclusive relation between the genotype and the phenotype. There is place between the genotype and the phenotype for an enormous set of considerably different factors which influence the passage from the genotype to the phenotype. First of all, external factors from the environment, such as temperature, air pressure, nutrition, etc., affect the final expression of a gene. Interestingly, some specific phenotypical traits are even "written" in the genetic script in the form of epigenetic marks, with methylation serving as an example (Švorcová, Markoš 2019).

Studies on evolvability and developmental biology cast new light on the complicated relation between the two opposite poles of the seeming transition from DNA script to the final product of protein biosynthesis. Illustrative explanations were proposed by genotype-phenotype maps (Alberch 1991; Pigliucci 2010). These maps were designed to explain the whole biological passage from a digital script 
to a three-dimensional body of an organism more complexly and graphically. As Massimo Pigliucci (2010: 564) noted,

[...] the undeniable progress we have made in understanding $G \rightarrow P$ maps, both empirically and theoretically, is such that one should hope that evolutionary biology has reached the point of forever being past simplistic ideas like genetic programmes and blueprints, embracing instead a more nuanced understanding of the complexity and variety of life.

The abandoning of the gene-centred model in biology in the last years has resulted in the need for replacing the old-fashioned binaristic approach in biology with a new theoretical apparatus. In the light of the theory of participative opposition, a compromise can be found between the binaristic approach and its total abandoning. Indeed, the notions of the genotype and the phenotype are still valid, and the power of binary explanations is strong enough to hold even after the discovery of epigenetic influence, developmental influence, and other factors entering the straightforward relation between the DNA script and its interpretation in the form of a living organism. The relation between the genotype and the phenotype is dyadic and it is a relation of opposition. However, it is a special kind of opposition, since the phenotype is much more than a blueprint of its genetic script: a phenotype is a materialization of its genetic script, but it is not only that. Therefore, we can say that the genotype participates in its phenotype (or vice versa: in the case of lateral gene transfer, for instance, it is a phenotype participating in a genotype).

The participative relation between the genotype and the phenotype is to be understood in an analogous way as was suggested about the relation between the content and the expression by Paolucci: we are not putting together one concrete genetic sequence and the phenotype it codes for, yet we are describing the very relation between the genotype and the phenotype in a general way. The answer to the question "what is the relation between the expression and the content?" is here analogous to the question "what is the relation between genotype and phenotype?". In the case of expression and content it is the scheme of A vs A + non- $\mathrm{A}$ in the form of $\mathrm{E} v s \mathrm{E}+$ non-E where $\mathrm{E}$ denotes the expression, and in the case of genotype and phenotype it is the scheme of $G$ vs $G$ + non- $G$ where $G$ denotes the genotype. It is a relation between intensive and extensive terms in which the extensive term is defined as an intensive term + non-intensive term.

The participative opposition has a strong potential to work as an explanatory tool in life sciences, the relation between the genotype and the phenotype being only one example of a much wider potential of applications. 
To conclude, participative opposition is not the only notion deriving from structural linguistics which is applicable to biology. Many other structuralist concepts can be taken to inspire or provide a new viewpoint to life phenomena. I can mention the concept of arbitrariness which was maybe the first one to link linguistics and biology: after the deciphering of the genetic code, many linguists became interested in seeking analogies between language and the genetic code, which has been viewed as a semiotic code in the strict sense (see Lacková et al. 2017). Jakobson may have been one of the pioneers in finding analogies between language and the genetic code (Jakobson 1971a). What the two semiotic systems share is their arbitrary nature: the genetic code was defined as a code because of the fact that it is based on the pairing between two different kinds of bio-molecules. This pairing is inexplicable without recurring to arbitrariness. Of course, in the case of the genetic code, the arbitrariness is a result of the biological evolution of species while in the case of natural language, the arbitrariness is a result of the socio-historical development of language. In both cases, arbitrariness and historicity are coextensive notions.

\section{Conclusion}

Even though Hjelmslev is usually described as a perfect example of one of the most meticulous representatives of the dualistic methods in structural linguistics, his not very widely known theory of participative oppositions demonstrates the contrary. Despite being binaristic, the theory of participative opposition enables such representations of language which are not strictly determined by exclusive logical laws. The structuralist era passed decades ago, yet we can still learn something new from its discoveries. The theory of participative oppositions might find a variety of possible applications in today's humanities - but not only there. The last section of this paper manifests how useful this theory can be in biology, particularly in genetics, and thus I believe that some forgotten messages from the structuralist era can find their place in the current state of science.

\section{References}

Alberch, Pere 1991. From genes to phenotype: Dynamical systems and evolvability. Genetica 84(1): 5-11. https://doi.org/10.1007/bf00123979

Andresen, Henning 1989. Markedness theory: The first 150 years. In: Tomić, Olga Mišeska (ed.), Markedness in Synchrony and Diachrony. Berlin, New York: Mouton de Gruyter, $11-46$. 
Chomsky, Noam 1957. Syntactic Structures. The Hague: Mouton.

Cantineau, Jean 1952. Les oppositions significatives. Cahiers Ferdinand de Saussure 10(3): 11-40.

Cantineau, Jean 1955. Le classement logique des oppositions. Word 11(1): 1-9. https://doi. org/10.1080/00437956.1955.11659546

Danesi, Marcel 2009. Opposition theory and the interconnectedness of language, culture, and cognition. Sign Systems Studies 37(1/2): 11-42. https://doi.org/10.12697/SSS.2009. 37.1-2.02

Dokulil, Miloš 1957. K otázce morfologických protikladů (Kritika předpokladu binárních korelací v morfologii češtiny). Slovo a Slovesnost 19(2): 81-103.

Faltýnek, Dan 2013. Konstruování gramatik DNA a proteosyntézy ze sémantické báze. In: Faltýnek, Dan; Gvoždiak, Vít (eds.), Tygramatika: Soubor studií věnovaných prof. Janu Kořenskému $k$ 75. narozeninám. Praha: Dokořán, 152-184.

Greimas, Algirdas Julien 1966. Sémantique structurale. Paris: Larousse.

Greimas, Algirdas Julien 1970. Du sens. Paris: Seuil.

Hjelmslev, Louis 1928. Principes de grammaire Générale. (Det Kgl. Danske Videnskabernes Selskab. Historisk-filologiske Meddelelser XVI, 1.) Copenhagen: A. F. Host and son.

Hjelmslev, Louis 1935. La catégorie des cas: étude de grammaire générale. (Acta Jutlandica 1.) Aarhus: Universitetsforlaget i Aarhus.

Hjelmslev, Louis 1942. Langue et Parole. Cahiers Ferdinand de Saussure 2: 29-44.

Hjelmslev, Louis 1963. Prolegomena to a Theory of Language. Madison: University of Wisconsin Press.

Hjelmslev, Louis 1985. Structure générale des correlations linguistiques. In: Hjelmslev, Louis; Rastier, François (eds), Nouveaux essais. (Formes Sémiotiques.) Paris: Presses Universitaires de France.

Huneman, Philippe 2010. Topological explanations and robustness in biological sciences. Synthese 177(2): 213-245. https://doi.org/10.1007/s11229-010-9842-Z

Huneman, Philippe 2018. Diversifying the picture of explanations in biological sciences: Ways of combining topology with mechanisms. Synthese 195(1): 115-146. https://doi. org/10.1007/s11229-015-0808-z

Jakobson, Roman 1932 The structure of the Russian verb. In: Jakobson, Roman; Waugh, Linda; Malle, Morris. Russian and Slavic Grammar: Studies 1931-1981. (Janua Linguarum Series Maior.) Berlin: De Gruyter.

Jakobson, Roman 1971a. Linguistics in relation to other sciences. In: Jakobson, Roman, Selected Writings. Vol. 2: Word and Language. The Hague: Mouton, 655-696.

Jakobson, Roman 1971b. Signe zero. In: Jakobson, Roman (ed.), Selected Writings. Vol. 2: Word and Language. The Hague: Mouton, 211-219.

Ketner, Kenneth; Beil, Ralph Gregory 2006. A Triadic Theory of Elementary Particle Interactions and Quantum Computation. Lubbock: Institute for Studies in Pragmaticism.

Ketner, Kenneth; Beil, Ralph Gregory 2012. Peirce, Clifford and quantum theory. In: Ketner, Kenneth (ed.), The Ralph Gregory Beil Memorial Volume: Papers in Theoretical Physics. Lubbock: Institute for Studies in Pragmaticism, 1957-1972.

Ketner, Kenneth et al. 2011. Peirce's nonreduction and relational completeness claims (CP 3.421): In the context of first-order predicate logic. KODIKAS/CODE: Ars Semeiotica 34 (Interdisciplinary Seminar on Peirce 2011), 3-14. 
Lacková, Ludmila 2019. Quelques remarques sur l'usage du terme «l'arbitraire du signe». In: Beziau, Jean-Yves (ed.), The Arbitrariness of the Sign in Question. London: College Publications, 283-294.

Lacková, Ludmila; Matlach, Vladimír; Faltýnek, Dan 2017. Arbitrariness is not enough: Towards a functional approach to the genetic code. Theory in Biosciences 136(3-4): 187-191. https://doi.org/10.1007/s12064-017-0246-1

Latour, Bruno 1988. The Pasteurization of France. (Sheridan, Alan; Law, John, trans.). Cambridge: Harvard University Press.

Latour, Bruno 1993. We Have Never Been Modern. (Porter, Catherine, trans.). Cambridge: Harvard University Press.

Lévy-Bruhl, Lucien 1927. Lâme primitive. Paris: Félix Alcan.

Lekomcev, Yuri K. 1974. The glossematic theory of linguistic oppositions and differentiation theory in semantics and descriptive semiotics. Linguistics 12(134): 37-72. https://doi. org/10.1515/ling.1974.12.134.37

Lindsley, Janet 2005. DNA Topology: Supercoiling and linking. In: Wiley Encyclopaedia of Life Sciences. Nature Publishing Company: John Wiley \& Sons. https://doi.org/10.1038/ npg.els.0003904

Lotman, Yuri 1991. Universe of the Mind: A Semiotic Theory of Culture. (Shukman, Ann, trans; Eco, Umberto, intr.) Bloomington: Indiana University Press.

Martinet, André 1957. Arbitraire linguistique et double articulation. Cahiers Ferdinand de Saussure 15: 105-16.

Nida, Eugene Albert 1979. Componential Analysis of Meaning: An Introduction to Semantic Structures (2nd ed.). The Hague: Mouton.

Paolucci, Claudio 2006. Lucien Tesnière autore della logica dei relativi. Su alcune insospettate corrispondenze tra Peirce e lo strutturalismo. E/C, 1-16.

Paolucci, Claudio 2010. Strutturalismo e interpretazione. Milano: Bompiani.

Paolucci, Claudio 2017. Logic of relatives and semiotics in Peirce: From the "subjectpredicate" inferential structure to the synechistic topology of interpretation. In: Švantner, Martin; Gvoždiak, Vít (eds.), How to Make Our Signs Clear. Leiden: Brill/Rodopi, 36-56. https://doi.org/10.1163/9789004347786

Peirce, Charles Sanders 1956[1923]. Chance, Love, and Logic: Philosophical Essays. New York: George Braziller.

Peirce, Charles Sanders 1931-1958. Collected Papers of Charles Sanders Peirce. Cambridge: Harvard University Press. (Vols. 1-6, Hartshorne, Charles; Weiss, Paul, eds., 19311935; vols. 7-8, Burks, Arthur W., ed., 1958) [In-text references are to CP, followed by volume and paragraph numbers.]

Peshkovskij, A. M. 2001[1928]. Russkij sintaksis v naucnom osvestsenii [Russian syntax from a scientific point of view]. Moscow: Jazyki russkoj kul'tury.

Pigliucci, Massimo 2010. Genotype-phenotype mapping and the end of the 'genes as blueprint' metaphor. Philosophical Transactions of the Royal Society B: Biological Sciences 365(1540): 557-566. https://doi.org/10.1098/rstb.2009.0241

Prieto, Luis Jorge 1960. Á propos de la commutation. Cahiers Ferdinand de Saussure 17: 53-63.

Saussure, Ferdinand de 2005[1916]. Cours de linguistique générale, (Edition critique de Tullio de Mauro.) Paris: Payot. 
Saussure, Ferdinand de 1916. Cours de linguistique générale. (Bally, Charles; Sechehaye, Albert, eds.) Paris: Payot.

Sedda, Franciscu 2017. Relationalism: From Greimas to hyperstructuralism. Sign Systems Studies 45(1/2): 16-32. https://doi.org/10.12697/SSS.2017.45.1-2.02

Švorcová, Jana; Markoš, Anton 2019. Epigenetic Processes and Evolution of Life. Boca Raton:

CRC Press. https://doi.org/10.1201/9781351009966

Tesniére, Lucien 1959. Éléments de syntaxe structural. Paris: Klincksieck.

Trubetzkoy, Nikolai Sergeyevich 1939. Grundzüge der Phonologie: Von N. S. Trubetzkoy.

Prague: Travaux du Cercle linguistique de Prague, Kraus Rekatseeksemplar.

\section{Применение партиципативной оппозиции}

Теория оппозиции - одно из главных достижений структурной лингвистики прошлого века. Хотя теория оппозиции по-прежнему используется в области фонологии, в других лингвистических дисциплинах она не имела успеха и была заменена другими теоретическими концепциями. Настоящая статья направлена на пересмотр теории оппозиции, в частности теории партиципативной оппозиции Л. Ельмслева. Данная оппозиция, вероятно, имеет высокий потенциал для применения не только в лингвистике, но и в других областях науки. В первой части статьи излагается краткая история теории бинарной оппозиции в рамках структурной лингвистики, во второй части вводится почти забытая к настоящему времени концепция партиципативной оппозиции, показываются её объяснительные возможности и возможности применения в биологии.

\section{Osalusopositsiooni rakendamine}

Opositsiooniteooria on üks eelmise sajandi strukturaallingvistika peamisi tulemusi. Kui fonoloogia vallas on see ikka veel kasutusel ja valiidne, ei ole seda saatnud samasugune edu teistes keeleteaduslikes distsipliinides, ning see on asendatud teiste teoreetiliste mõistetega. Käesolevas artikli eesmärgiks on pöörduda tagasi opositsiooniteooria juurde, eriti Hjelmslevi poolt välja pakutud osalusopositsiooni teooria juurde. Osalusopositsioonil näib olevat kõrge rakenduslik potentsiaal mitte üksnes keeleteaduses, vaid ka teistes teadusvaldkondades. Artikli esimeses osas visandatakse lühidalt binaarsete opositsioonide teooria ajalugu strukturaallingivistikas ning teises osas tutvustatakse osalusopositsiooni üsnagi unustatud mõistet ja näidatakse selle selgitusjõudu ning viimaks ka selle üht rakendusvõimalust bioloogias. 